\title{
Upaya Meningkatkan Hasil Belajar Ekonomi dengan Menggunakan Model Belajar Kooperatif Teams Games Tournament (TGT) di Kelas XI IIS2 MAN-1 Pekanbaru Tahun Pelajaran 2017-2018
}

\author{
Syafni Ermayulis \\ Guru MAN 1 Pekanbaru
}

\begin{tabular}{l}
\hline \hline \multicolumn{1}{c}{ INFO ARTIKEL } \\
\hline Riwayt Artikel: \\
Diterima: 22-04-2020 \\
Disetujui: 29-04-2020 \\
\hline Kata kunci: \\
Model Belajar Kooperatif \\
Teams Games Tournament (TGT), \\
Hasil Belajar Ekonomi, \\
Peserta Didik
\end{tabular}

\section{Alamat Korespondensi:}

Syafni Ermayulis

Guru MAN 1 Pekanbaru

E-mail: syafniermayulis@gmail.com

ABSTRAK

Abstract: Education is an activity to help students develop their educational goals. Educational activities are core interactions between students and educators and other educational resources, and take place in an educational environment. One of the ways to improve the quality of education is through the use of various learning models. One learning model that can be developed to improve learning outcomes is the Teams Games Tournament (TGT) model. Economic lessons as one of the mandatory subjects for iis majors students also require innovative learning models to improve learning outcomes. This study aims to see an increase in student learning outcomes in class XI IIS2 MAN-1 in economics by using the Teams games tournament learning model. This type of research is classroom action research. The study was conducted in 2 cycles, each of which consisted of four stages, namely: 1) planning. 2) implementation. 3) observation. 4) reflection. The study was conducted in January-February 2018. The first cycle was conducted in 3 meetings and the second cycle was carried out in 3 meetings. The results showed that there was an increase in completeness of learning outcomes by $26.8 \%$ from cycle 1 to cycle 2 . The category of knowledge also increased by $57.3 \%$ in the criteria of very good and good from cycle 1 to cycle 2.

Abstrak: Pendidikan merupakan kegiatan untuk membantu perkembangan peserta didik mencapai tujuan-tujuan pendidikan. Kegiatan pendidikan berintikan interaksi antara peserta didik dengan pendidik dan sumber-sumber pendidikan lain, dan berlangsung dalam suatu lingkungan pendidikan. Peningkatan kualitas pendidikan harus terus dilaksanakan salah satunya dengan penggunaan berbagai model pembelajaran. Salah satu model pembelajaran yang dapat dikembangkan untuk meningkatkan hasil belajar adalah model Teams Games Tournament (TGT). Pelajaran ekonomi sebagai salah satu mata pelajaran wajib bagi siswa jurusan is juga memerlukan inovasi model pembelajaran agar meningkatkan capaian hasil belajar. Penelitian ini bertujuan untuk melihat peningkatan hasil belajar siswa kelas XI IIS2 MAN-1 pada pelajaran ekonomi dengan menggunakan model pembelajaran teams games tournament. Jenis penelitian yang dilakukan adalah penelitian tindakan kelas. Penelitian dilakukan dalam 2 siklus yang masing-masing terdiri dari empat tahapan, yaitu :1) perencanaan. 2) pelaksanaan. 3) pengamatan. 4) refleksi. Penelitian dilakukan pada bulan januari-februari 2018. Siklus pertama dilakukan dalam 3 kali pertemuan dan siklus ke 2 dilakukan dalam 3 pertemuan. Hasil penelitian menunjukkan bahwa terjadi peningkatan ketuntasan hasil belajar sebesar 26, 8\% dari siklus 1 ke siklus 2. Kategori pengetahuan juga meningkat sebesar 57,3\% pada kriteria amat baik dan baik dari siklus 1 ke siklus 2 . 


\section{LATAR BELAKANG}

Dalam Lingkup mikro, pendidikan diwujudkan melalui proses belajar mengajar di dalam kelas maupun di luar kelas. Proses ini berlangsung edukatif. Melalui proses belajar mengajar inilah peserta didik akan mengalami proses perkembangan kearah yang lebih baik dan bermakna agar hal tersebut dapat terwujud maka diperlukan suasana proses belajar mengajar yang kondusif bagi peserta didik dalam melampaui tahapan-tahapan belajar secara bermakna dan efektif sehingga menjadi pribadi yang percaya diri, inovatif dan kreatif (Surya, 1992). Sistem pendidikan saat ini telah mengalami kemajuan yang pesat. Berbagai strategi dan model pembelajaran diterapkan dalam proses belajar mengajar, dengan harapan pengajaran guru akan lebih berkesan dan bermakna bagi siswa. Proses kegiatan belajar mengajar di dalam kelas harus diterapkan dengan menggunakan berbagai metode pembelajaran, dengan harapan siswa sebagai subjek didik dapat menerima bahan pelajaran dengan baik dan memberikan hasil yang memuaskan.

Setiap proses pembelajaran yang berlangsung harus memperhatikan potensi individual siswa serta kinerja otak dan emosi. Metode pengajaran tersebut harus dapat mengaktifkan tidak hanya otak kiri tetapi juga otak kanan. Karena diketahui bahwa otak kanan memiliki kemampuan berpikir imajinatif, holistic dan kreatif serta bisa menghasilkan ide-ide di luar pakem yang biasa diamati otak kiri (Asbullah,2008). Penggunaan otak kiri dan kanan secara bersama diharapkan dapat menghasilkan keseimbangan yang akhirnya meningkatkan penguasaan materi pelajaran. Berdasarkan hasil pengamatan dan pengalaman peneliti selama ini, dari beberapa kelas yang peneliti ampu, di kelas XI IIS 2 adalah kelas yang teridentifikasi memiliki hasil belajar yang rendah. Hasil ulangan harian dari beberapa kompetensi dasar, sebagai indikator ketercapaian hasil belajar, masih banyak yang belum mencapai KKM. Hasil ulangan harian beberapa kompetensi dasar, di kelas XI IIS 2 dapat dilihat pada Tabel 1.

Tabel 1. Ketuntasan Belajar Ulangan Harian Beberapa Kompetensi Dasar Kelas XI IIS2 MAN 1 Pekanbaru Tahun 2017/2018 (Jumlah Siswa 30)

\begin{tabular}{|c|c|c|c|c|c|c|}
\hline \multirow[t]{2}{*}{ No } & \multirow[t]{2}{*}{ Kompetensi Dasar } & \multirow[t]{2}{*}{ KKM } & \multicolumn{2}{|c|}{$\begin{array}{l}\text { Jumlah } \\
\text { Siswa } \\
\text { Tuntas }\end{array}$} & \multicolumn{2}{|c|}{$\begin{array}{l}\text { Jumlah } \\
\text { Siswa Tidak } \\
\text { Tuntas } \\
\end{array}$} \\
\hline & & & $\mathrm{f}$ & $\%$ & $\mathrm{f}$ & $\%$ \\
\hline 1 & $\begin{array}{l}\text { Mendeskripsikan konsep dan metode penghitungan } \\
\text { pendapatan nasional }\end{array}$ & 80 & 10 & 33,3 & 20 & 66.7 \\
\hline 2 & $\begin{array}{l}\text { Mendeskripsikan konsep pertumbuhan ekonomi } \\
\text { dan pembangunan ekonomi serta permasalahan dan } \\
\text { cara mengatasinya }\end{array}$ & 80 & 13 & 43,3 & 17 & 56,7 \\
\hline
\end{tabular}

Sumber Data: Daftar Nilai Guru Ekonomi Kelas XI IIS2 MAN 1 Pekanbaru

Rendahnya hasil ulangan harian siswa disebabkan oleh kurangnya motivasi siswa dalam belajar. Guru masih kesulitan untuk memotivasi dan menumbuhkan minat belajar. Pengajaran yang dilakukan saat ini lebih banyak dilakukan dengan menulis, membaca dan mendengarkan dengan subjek yang paling berperan dipegang oleh guru. Seorang guru sering kali menggunakan metode ceramah dalam menyampaikan pelajaran. Siswa tidak dapat secara maksimal memanfaatkan potensinya karena terlalu bersifat teacher center. Jika metode ini terlalu sering digunakan maka dipastikan dapat menimbulkan kejenuhan karena tidak ada warna baru dalam kegiatan belajar mengajar. Sulitnya penguasaan dan pemahaman materi oleh siswa melalui metode ceramah terjadi pada sebagian besar pelajaran, tidak terkecuali mata pelajaran ekonomi.

Ekonomi sebagai salah satu mata pelajaran yang diajarkan disekolah menengah sering dianggap pelajaran yang sulit. Dimulai dari penghapalan teori-teori ekonomi, soal-soal hitungan , sering membuat para siswa merasa kesulitan dalam memahami sebagian besar materi dan konsep hitungan. Upaya meningkatkan pemahaman siswa terhadap materi pelajaran, khususnya mata pelajaran ekonomi 
tersebut, perlu diterapkan model pengajaran yang lebih efektif. Penerapan model pengajaran, diharapkan dapat meningkatkan penguasaan dan pemahaman siswa terhadap materi yang diajarkan. Ketersediaan waktu pembelajaran juga merupakan salah satu faktor yang dapat menjadi pertimbangan metode apa yang akan digunakan seorang guru dalam menyampaikan materinya.

Berdasarkan masalah yang dikemukakan di atas, perlu dilakukan tindakan di kelas XI IIS-2, dan dari hasil tindakan yang diberikan diharapkan hasil belajar siswa meningkat. Oleh karena itu, PBM perlu menempatkan siswa sebagai subjek belajar, dan mengembangkan potensi dan kemampuan sosialnya secara optimal, karena siswa akan lebih mudah membangun dan menegembangkan pemahaman melalui interaksi sosial. Model pembelajaran yang diterapkan untuk peningkatan pemahaman siswa dalam pelajaran ekonomi adalah model Teams Games Tournament (TGT). Model belajar ini lebih banyak melibatkan siswa secara aktif dalam mendiskusikan materi pelajaran dan membahas soal-soal dengan kompetisi antar kelompok. Dinamika kompetisi akan meningkatkan daya saing sehingga siswa akan berperan lebih aktif, apalagi jika soal-soal dibahas dengan menggunakan suatu permainan. Suasana kompetisi juga akan menghidupkan kelas dan membangun semangat, terlebih lagi jika jam pembelajaran dilakukan siang hari. Dengan demikian materi-materi yang susah dipelajari diharapkan lebih mudah dipahami. Banyak ahli berpendapat bahwa model pembelajaran kooperatif unggul dalam membantu siswa memahami konsep-konsep sulit. Pembelajaran kooperatif juga menurut mereka memberikan efek terhadp sikap penerimaan perbedaan antar individu baik ras, keagamaan, gender, social ekonomi dan lain-lain. Selain itu yang terpenting pembelajaran kooperatif mengajarkan keterampilan bekerja sama dalam kelompok atau team work. Keterampilan ini sangat dibutuhkan anak saat nanti lepas ke tengah masyarakat.

Ada 6 langkah utama didalam melaksanakan pembelajaran kooperatif seperti yang diungkapkan Streeter (1999). Keenam langkah itu adalah: pembelajaran dimulai dengan guru menyampaikan tujuan pembelajaran dan memotivasi siswa untuk belajar. Langkah ini kemudian diikuti oleh penyajian informasi baik berupa bahan bacaan maupun informasi verbal lainnya. Selanjutnya siswa dikelompokkan ke dalam kelompok-kelompok belajar. Tahap ini diikuti dengan bimbingan oleh guru pada saat siswa belajar dalam kelompok. Lalu guru memberikan evaluasi tentang hal-hal yang telah mereka pelajari dan kemudian memberikan penghargaan terhadap usaha-usaha yang telah dilakukan oleh individu maupun oleh kelompok. Model pembelajarn kooperatif mempunyai banyak sekali variasi. Salah satu diantaranya adalah model pembelajaran kooperatif tipe Teams Games Tournament (TGT). Menurut Saco (2006) dalam TGT siswa memainkan permainan-permainan dengan anggota-anggota tim kelompok lain untuk memperoleh skor bagi tim mereka masing-masing. Permainan dapat disusun oleh guru dalam bentuk kuis berupa pertanyaan-pertanyaan yang berkaitan dengan materi pelajaran. Kadang-kadang juga dapat diselingi dengan pertanyaan yang berkaitan dengan identitas kelompok.

Permainan dalam TGT dapat berupa pertanyaan-pertanyaan yang ditulis pada kartu-kartu yang diberi angka. Tiap siswa misalnya akan mengambil sebuah kartu yang diberi angka tadi dan berusaha untuk menjawab pertanyaan yang sesuai dengan angka tersebut. Turnament harus memungkinkan semua siswa dari berbagai tingkatan kemampuan untuk menyumbangkan point bagi kelompoknya. Prinsipnya, soal sulit untuk anak pintar dan soal yang lebih mudah untuk anak yang kurang pintar. Hal ini dimaksudkan agar semua anak mempunyai kemungkinan memberi skor bagi kelompoknya. Permainan yang dikemas dalam bentuk tournament ini dapat berperan sebagai penilaian alternative atau dapat pula sebagai review materi pelajaran. Pola model TGT ini juga diharapkan dapat meningkatkan hasil belajar pembelajaran ekonomi. Secara umum TGT sama saja dengan STAD kecuali satu hal: TGT menggunakan Turnamen Akademik, dan menggunakan kuis-kuis dan sistem skor kemajuan individu, di mana para siswa berlomba-lomba sebagai wakil tim meraka dengan anggota tim lain yang kinerja akademik sebelumnya setara seperti mereka. TGT sangat sering digunakan dengan STAD, dengan menambahkan turnamen tertentu pada struktur STAD yang biasanya (Robert E. Slavin, 2010). Dalam TGT peserta didik memainkan permainan-permainan dengan anggota tim lain untuk memperoleh skor bagi tim mereka masing-masing. Penyusunan permainan dapat disusun dalam bentuk kuis berupa pertanyaan yang berkaitan dengan materi pelajaran. Model Pembelajaran Kooperatif tipe 
Teams-Games-Tournament (TGT), atau pertandingan permainan tim dikembangkang secara asli oleh David De Vries dan Keath Edward (1995). Pada Model ini siswa memainkan permainan dengan anggota-anggota tim lain untuk memperoleh tambahan poin untuk skor tim mereka. (Trianto, 2010)

Langkah-langkah TGT disajikan dalam beberapa tahapan yaitu: 1). Presentasi Kelas (Penyajian Kelas) Sama seperti dalam STAD, yaitu: Materi dalam TGT pertama- tama diperkenalkan dalam presentasi di dalam kelas. Ini merupakan pengajaran langsung seperti yang sering kali dilakukan atau diskusi pelajaran yang dipimpin oleh guru, tetapi bisa juga memasukkan presentasi Audiovisual. Bedanya presentasi kelas dengan pengajaran biasa hanyalah bahwa presentasi tersebut haruslah benar-benar berfokus pada TGT. Dengan cara ini, para siswa akan menyadari bahwa mereka harus benar-benar memberi perhatian penuh selama presentasi kelas, karena dengan demikian akan sangat membantu mereka mengerjakan kuis-kuis/game-game, dan skor kuis mereka menentukan skor tim mereka. 2) Kelompok (tim) Tim terdiri dari empat atau lima siswa yang mewakili seluruh bagian dari kelas dalam hal kinerja akademik, jenis kelamin, ras dan etnistas. Fungsi utama dari tim ini adalah memastikan bahwa semua anggota tim benar-benar belajar, dan lebih khususnya lagi, adalah untuk mempersiapkan anggotanya untuk bisa mengerjakan kuis dengan baik. Setelah guru menyampaikan materinya, tim berkumpul untuk mempelajari lembar-kegiatan atau materi lainnya. Yang paling sering terjadi, pembelajaran itu melibatkan pembahasan permasalahan bersama, membandingkan jawaban, dan mengoreksi tiap kesalahan pemahaman apabila anggota tim ada yang membuat kesalahan. 3) Game, Gamenya terdiri atas pertanyaan-pertanyaan yang kontennya relevan yang dirancang untuk menguji pengetahuan siswa yang diperolehnya dari presentasi di kelas dan pelaksanaan kerjaa tim. Game tersebut dimainkan di atas meja dengan tiga orang siswa, yang masing-masing mewakili tim yang berbeda. Permainan games tersebut dapat juga diterapkan dalam pelajaran ekonomi. Ada banyak kesalahan konsep yang selama ini berkembang dalam pengelolaan belajar ekonomi di dalam kelas. Kegiatan belajar ekonomi berubah menjadi kegiatan mengajar ekonomi. Dengan kegiatan mengajar, maka pusat kegiatan adalah guru. Sepanjang jam pelajaran harus memberikan ceramah dan siswa duduk memperhatikan. Dalam kegiatan belajar ekonomi, siswa yang menjadi pusat kegiatan atau subyek belajar.

Belajar ekonomi adalah salah satu pelajaran yang wajib untuk diketahui, walaupun sebagian orang mungkin kurang berminat untuk mempelajarinya. Ekonomi adalah salah satu sektor yang penting yang menjadi dasar kehidupan manusia. Segala sesuatu yang membuat manusia berinteraksi dan melakukan transaksi dibahas dalam ilmu ekonomi. Seiring dengan perkembangan jaman dan ilmu pengetahuan muncullah ilmu yang disebut ilmu ekonomi. Menurut Paul A. Samuelson (Sukwiaty, dkk, 2009) mengemukakan bahwa: "Ilmu ekonomi sebagai suatu studi tentang perilaku orang dan masyarakat dalam memilih cara menggunakan sumber daya yang langka dan memiliki beberapa alternatif penggunaan, dalam rangka memproduksi berbagai komoditas, untuk kemudian menyalurkannya, baik saat ini maupun di masa depan kepada berbagai individu dan kelompok yang ada dalam suatu masyarakat". Berdasarkan uraian tersebut maka dapat disimpulkan bahwa mata pelajaran ekonomi adalah bagian dari mata pelajaran di sekolah yang mempelajari perilaku individu dan masyarakat dalam usaha memenuhi kebutuhan hidupnya yang tak terbatas dengan alat pemuas kebutuhan yang terbatas jumlahnya. Sebuah proses pembelajaran yang baik hendaknya tidak hanya mengacu pada tujuan / hasil belajar sampai pada domain kognitif saja, sebaiknya harus menunjukan keseimbangan antara tiga aspek yaitu kognitif, afektif, dan psikomotorik. Karena hakikatnya, tujuan pembelajaran adalah sebagai arah dari proses belajar mengajar yang diharapkan mampu mewujudkan rumusan tingkah laku yang dapat dikuasai siswa setelah siswa menempuh pengalaman belajarnya.

Mata pelajaran ekonomi bertujuan agar peserta didik memiliki kemampuan sebagai berikut: 1) Memenuhi sejumlah konsep ekonomi yang berkaitan peristiwa dan masalah ekonomi dengan kehidupan sehari-hari. Terutama yang terjadi di lingkungan individu, rumah tangga, masyarakat dan Negara; 2) Menampilkan sikap ingin tahu dan terhadap sejumlah konsep ekonomi yang diperlukan untuk mendalami ilmu ekonomi; 3) Membentuk sikap bijak, rasional, dan bertanggung jawab dengan memiliki pengetahuan dan keterampilan ilmu ekonomi, manajemen, dan akuntansi yang bermanfaat 
bagi diri sendiri, rumah tangga, masyarakat dan Negara; 4) Membuat keputusan yang bertanggung jawab mengenai nilai-nilai sosial ekonomi dalam masyarakat yang majemuk, baik dalam skala nasional maupun internasional (Permen 22 Tahun 2006-Standar Isi/Standar Kompetensi Dasar SM). Ditinjau dari pihak guru materi pembelajaran itu harus diajarkan atau disampaikan dalam kegiatan pembelajaran. Ditinjau dari pihak siswa bahan ajar itu harus dipelajari siswa dalam rangka mencapai standar kompetensi dan kompetensi dasar yang akan dinilai dengan menggunakan instrumen penilaian yang disusun berdasarkan indikator pencapaian belajar.

Berdasarkan penjelasan di atas dapat disimpulkan bahwa mata pelajaran ekonomi bukanlah mata pelajaran yang bersifat hafalan, sehingga siswa harus diajarkan untuk berekonomi dengan mengenal berbagai kenyataan dan peristiwa ekonomi yang terjadi secara nyata maka pembelajaran ekonomi perlu menggunakan metode pembelajaran yang kreatif dan inovatif sesuai dengan apa yang dibutuhkan oleh siswa serta disesuaikan dengan kondisi agar tujuan pembelajaran dapat tercapai. Dengan demikian, proses belajar mengajar ekonomi bukan sekedar transfer ilmu dari guru kepada siswa, sehingga interaksi belajar terjadi antara guru dengan siswa. Pola interaksi seharusnya terjadi antara siswa dengan materi (obyek) dan guru hanya bertindak sebagai pengendali.

\section{METODE}

Penelitian ini adalah Penelitian Tindakan Kelas (PTK) atau Classroom Action Research merupakan suatu model penelitian yang diterapkan di kelas dengan Model Teams Games Tournament. Dengan metode ini dimungkinkan adanya korelasi antara variable bebas dengan variable terikat. Variabel terikat dalam hal ini adalah hasil belajar sedangkan variable bebas adalah model Teams Games Tournament. Penelitian ini dilaksanakan di MAN 1 Pekanbaru di kelas XI IIS 2 dengan jumlah siswa 30 orang terdiri dari 17 siswi dan 13 siswa. Penelitian ini dilaksanakan pada semester 2 (genap) Tahun Pembelajaran 2017-2018 pada saat mata pelajaran Ekonomi kelas XI IIS 2 MAN 1 Pekanbaru, dengan materi yang disajikan pelajaran Ekonomi yang disusun untuk setiap pertemuan dalam Rencana Pelaksanaan Pembelajaran (RPP). Desain penelitian tindakan kelas terdiri atas empat tahapan, yaitu : 1) perencanaan. 2) pelaksanaan. 3) pengamatan. 4) refleksi. Di dalam pelaksanaan penelitian ini akan menggunakan beberapa siklus, setiap berakhir pada satu siklus akan direpleksikan pada siklus berikutnya:

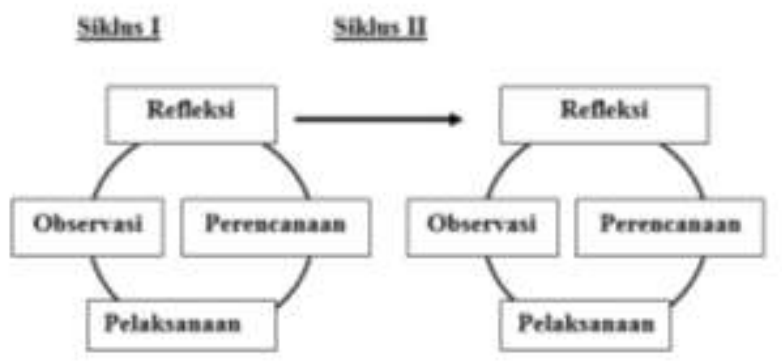

Gambar 1. Desain Penelitian Tindakan Kelas

Prosedur penelitian melalui tahapan pembelajaran yakni perencanaan, tindakan, observasi dan refleksi.

\section{Perencanaan}

Tahapan ini merupakan tahap perencanaan dalam melakukan tindakan untuk menentukan rencana tindakan penelitian adalah: 1) Kegiatan pendahuluan, kegiatan inti, kegiatan penutup yang disesuaikan dengan metode pemberian lembaran tugas dan menjawab pertanyaan; 2) Memilih pokok bahasan untuk penerapan pembelajaran dengan pemberian lembaran tugas, dengan kompetensi dasar penelitian ini adalah dengan membuat silabus, RPP dan LKS; 3) Menentukan kelompok belajar dengan jumlah masing-masing 5/6 orang siswa; 4) Merencanakan lembaran observasi dengan untuk mengamati aktivitas siswa dalam menjawab pertanyaan-pertanyaan; 5) Menyiapkan alat evaluasi berupa penilaian hasil kerja kelompok (LKS ) dan individu dan membuat soal-soal ulangan harian, dengan KKM 80 dengan target pencapaian $75 \%$ tuntas dan yang tidak tuntas diadakan remedial. Yang tidak 
tuntas menjadi acuan untuk melakukan penelitian siklus ke II; dan 6) Merencanakan refleksi setiap akhir siklus dilaksanakan

\section{Tindakan}

Kegiatan yang dilaksanakan adalah melaksanakan RPP yang direncanakan. Pelaksana tindakan adalah peneliti sebagai guru Ekonomi. Pelaksanaan penelitian bersamaan dengan observasi dan melakukan pengisian lembaran observasi, terdiri dari beberapa siklus dengan : Menetapkan pelaksanaan jumlah siklus bergantung hasil siklus I dan Melaksanakan pembelajaran kooperatif Model Teams games Tournament. Model adalah representasi realitas yang disajikan dengan suatu derajat struktur dan urutan. TGT adalah penerapan model belajar dengan cara mengelompokkan siswa secara heterogen, setelah memperoleh tugas setiap kelompok bekerja sama dalam bentuk kerja individual dan diskusi. Suasana diskusi dibuat senyaman mungkin seperti dalam kondisi suatu permainan. Langkahlangkah pembelajaran TGT: 1) Guru membagi kelas dalam beberapa kelompok heterogen; 2) Guru menjelaskan maksud pembelajaran dan tugas kelompok; 3) Siswa berdiskusi mengerjakan tugas kelompok dan tugas individu; 4) Guru mempersiapkan kartu-kartu berisi soal sesuai dengan materi yang diberikan pada bahan diskusi kelompok. Soal pada kartu memiliki tingkat kesukaran yang berbeda; 5) Untuk menjawab soal pada kartu, disiapkan beberapa meja tournament, tiap meja ditempati 1 siswa dengan kemampuan setara. Meja 1 diisi dengan level tertinggi dari tiap kelompok dan seterusnya sampai meja ke 4 ditempati oleh siswa yang levelnya paling rendah. Penentuan tiap siswa yang duduk pada meja tertentu adalah hasil kesepakatan kelompok; 6) Selanjutnya adalah pelaksanaan tournament, setiap siswa mengerjakan kartu soal yang telah disediakan pada tiap meja untuk jangka waktu tertentu ( misalnya 2-3 menit); 7) Setelah siswa mengerjakan soal dan hasilnya diperiksa dan diperoleh skor nilai individu sekaligus skor kelompok; 8) Siswa pada tiap meja tournament diberi gelar sesuai dengan skor yang diperoleh dengan sebutan superior, very good, good dan seterusnya; 9) Untuk soal soal pada kartu berikutnya dilakukan dengan cara yang sama; 10) Hasil jawaban dari para siswa dijadikan bahasan dan penarikan kesimpulan materi; 11) Evaluasi. Melaksanakan evaluasi berupa format penilian hasil kerja kelompok dan individu dan membuat soalsoal ulangan harian, dengan KKM 80 dengan target pencapai $75 \%$ tuntas dan yang tidak tuntas diadakan remedial. Yang tidak tuntas menjadi acuan untuk melakukan refleksi pada penelitian siklus ke II; dan 12) penutup.

\section{Observasi}

Kegiatan observasi dilaksanakan bersamaan dengan pelaksanaan pembelajaran sedang berlangsung yang dilakukan oleh 1 orang observer untuk mengamati aktifitas siswa dan guru selama proses belajar mengajar, evaluasi hasil kerja kelompok dan individu dilaksanakan setiap pertemuan dan evaluasi akhir berupa ulangan harian diakhir siklus.

\section{Refleksi}

Refleksi merupakan cara berfikir ulang tentang apa yang baru dipelajari atau berfikir apa yang sudah dilakukan di masa lalu. Dapat juga dikatakan refleksi adalah merupakan respon terhadap kejadian, aktvitas atau pengetahuan baru diterima. Data yang diperoleh dari hasil observasi, selanjutnya di refleksikan untuk melakukan tindakan pada siklus berikutnya. Evaluasi pelaksanaan pembelajaran merumuskan dan mengidentifikasi masalah pada pelaksanaan dan respon siswa pada siklus I yang menjadi acuan untuk melaksankan proses pembelajaran pada siklus ke II yang pelaksanaannya sama dengan siklus I, jika belum berhasil dilanjutkan dengan siklus ke III yang permasalahan berasal identifikasi pelaksanaan siklus ke II. Penelitian dihentikan apa bila sudah mencapai ketuntasan pelajar sesuai dengan yang diinginkan oleh peneliti. Pelaksanaan siklus ke II dapat direncang sebagai beikut: 1) Dirancang bersifat tentative/alternatif; 2) Pembelajaran pada siklus ke II dilakukan berdasarkan rekomendasi dari hasil refleksi siklus pertama; 3) Observasi aktivitas pembelajaran siswa dilakukan oleh observer selama pelaksanaan tindakan; 4) Mengevaluasi pelaksanaan tindakan; 5) Menganalisis pencapaian belajar siswa; dan 6) Menganalisis data hasil observasi dan evaluasi. 
Pelaksanaan refleksi ini bertujuan untuk mengetahui keberhasilan tindakan-tindakan pelaksanaan proses pembelajaran secara menyeluruh. Teknik pengumpulan data yang digunakan adalah teknik prosentase yaitu membandingkan munculnya terhadap keseluruhan dikalikan dengan $100 \%$. Instrumen berupa lembaran observasi aktifitas siswa, sedangkan tes hasil belajar untuk mengetahui ketuntasan individu di tetapkan KKM 80 dan ketuntasan secara klasikal $75 \%$ sudah mencapai standar ketuntasan minimal. Data dalam penelitian ini dijaring oleh instrumen penelitian berupa test tertulis, dan lembaran observasi. Test digunakan untuk mengetahui hasil belajar siswa setelah dilakukan perlakuan, yang pelaksanaannya pada setiap siklus. Validasi instrumen yang dilakukan oleh validator adalah sebagai berikut : Rencana rancangan pembelajaran, aktifitas siswa dan soal-soal. Dalam penelitian ini instrument yang digunakan berupa tes objektif dalam bentuk pilihan ganda. Data yang dikumpulkan adalah data kuantitatif. Menurut BNSP Departemen Pendidikan Nasional (2006) pengolahan hasil belajar untuk pemahaman konsep dengan soal objektif dirumuskan sebagai berikut.

$$
\text { Nilai }=\frac{\text { Banyaknya jawaban benar }}{\text { Jumlah soal }} \times 10 \%
$$

Dari hasil data dengan menggunakan rumus tersebut dapat disimpulkan kriteria interval pemahaman konsep sebagai berikut.

$$
\begin{array}{ll}
85-100 & =\text { amat baik } \\
70-84 & =\text { baik } \\
50-69 & =\text { cukup } \\
30-49 & =\text { kurang }
\end{array}
$$

\section{HASIL DAN PEMBAHASAN}

Penelitian ini merupakan penelitian tindakan kelas yang dilakukan dalam 2 siklus yang sebelumnya diadakan pembentukan kelompok oleh guru. Pembagian kelompok dilakukan secara heterogen dimana setiap kelompok memiliki kemampuan yang beragam. Tindakan yang dilakukan berupa penerapan pembelajaran kooperatif tipe TGT. Siklus 1 dilakukan dalam 3 kali dengan materi pelajaran Menjelaskan pengertian BUMN dan BUMD, Menjelaskan peran BUMN dan BUMD dalam perekonomian, Menjelaskan bentuk-bentuk BUMN dan BUMD, Menjelaskan jenis-jenis Kegiatan Usaha BUMD, Menjelaskan kebaikan dan kelemahan BUMN dan BUMD, Sedangkan siklus ke dua dilakukan dalam 3 kali pertemuan dengan materi Menjelaskan pengertian BUMS, Menjelaskan perbedaan perusahaan swasta dan BUMS, Menjelaskan peran BUMS dalam perekonomian, Menjelaskan bentuk-bentuk BUMS, Menjelaskan kekuatan dan kelemahan BUMS, Menjelaskan jenisjenis kegiatan usaha BUMS, Menjelaskan tahapan mendirikan usaha dalam BUMS. Data yang dikumpulkan berupa hasil belajar siswa dalam ulangan harian maupun dalam menjawab soal-soal pada tournament.

Untuk permainan games anggota kelas dibagi menjadi 5 kelompok. Tiap kelompok memiliki tingkat kecerdasan yang heterogen. Setiap kelompok menentukan sendiri siswa mana yang akan menjawab pertanyaan dari tingkat kesukaran tinggi hingga soal termudah. Kriteria soal yang disiapkan guru dalam kartu-kartu TGT untuk tournament terdiri atas kategori: Soal A: Sangat sulit; Soal B: Sulit; Soal C: Sedikit sulit; Soal D: Sedang; dan Soal E: Mudah.

\section{Hasil siklus 1}

\section{Tahap Perencanaan dan Tindakan}

Berdasarkan perencanaan yang sudah disusun, maka siklus 1 dilaksanakan dalam 3x pertemuan yaitu : pertemuan pertama hari selasa tanggal 16 januari 2018, pertemuan kedua hari selasa tanggal 23 januari 2018, pertemuan ketiga hari selasa tanggal 30 januari 2018, Dan pada tanggal 6 februari 2018 dilaksanakan tes hasil belajar siklus I. Pada tahap ini setelah guru menyampaikan materi pengertian bumn, peran dan bentuk-bnetuk bumn dan bumd, maka siswa kemudian diarahkan untuk duduk berkelompok dan mengerjakan LKS yang diberikan. Dalam pengerjaan LKS siswa dapat berdiskusi 
antara sesama anggota di dalam kelompoknya. Setelah pelaksanaan pengerjaan LKS maka salah satu perwakilan anggota kelompok menyampaikan hasil kerja LKS nya. Penyampaian ini hanya diberi waktu 5-10 menit sebagai bukti ketuntasan siswa dalam mengerjakan LKS yang telah diberikan. Pada saat kegiatan mengerjakan LKS, observer mengamati proses belajar. Pertemuan pertama berlangsung pada selasa tanggal 16 februari 2018, proses kegiatan belajar dimulai dengan Tanya jawab materi yang akan dipelajari, mengkomunikasikan tujuan pelajaran yang akan dicapai, menjelaskan kegiatan kooperatif TGT yang akan dilaksanakan dan memotivasi siswa. Siswa dalam kelompok secara kooperatif menyelesaikan materi belajar sesuai kompetensi dasar yang akan dicapai. setelah itu guru mengarahkan siswa untuk mengajukan pertanyaan tentang informasi yang tidak dipahami dari apa yang diamati atau pertanyaan untuk mendapatkan informasi tambahan tentang apa yang diamati, Guru membagikan tugas mendiskusikan materi yang dipelajari. Selama proses pembelajaran dari awal sampai akhir semua kegiatan diamati dan dinilai oleh 1orang observer.

Pertemuan kedua pada penelitian ini berlangsung pada hari selasa tanggal 23 februari 2018, pembelajaran dilanjutkan dengan materi jenis-jenis kegiatan usaha bumd dan menjelaskan kebaikan dan kelemahan bumn dan bumd. Pembelajaran dilaksanakan sesuai dengan langkah pembelajaran pada RPP yaitu sama dengan pertemuan pertama, hanya saja sebelum pembelajaran dimulai, guru mengecek kembali pemahaman siswa tentang materi sebelumnya. Pertemuan Ketiga dilakukan pada hari selasa tanggal 30 januari 2018, pada pertemuan ke tiga siswa telah semakin aktif berdiskusi di kelompoknya. siswa sudah mulai menunjukan perahatian yang baik dengan memperhatikan apa yang disampaikan guru.

\section{Tahap bermain Games Tournament}

Setiap anggota di kelompok berdiskusi untuk menentukan soal yang mana yang akan dijawab oleh tiap-tiap anggota dalam kelompok. Apakah tipe soal A dengan kategori Sangat sulit, Soal B kategori Sulit, Soal C kategori Sedikit sulit, Soal D kategori Sedang dan Soal E kategori. Pemilihan menjawab soal didasarkan kesepakatan siswa tanpa ada campur tangan dari guru. Setelah ditentukan tipe soal untuk masing-masing individu siswa maka tiap individu di kelompok berlatih untuk menjawab soal-soal di dalam kelompoknya. Setelah berlatih pada kelompok masing-masing, maka turnament dimulai dengan cara memanggil setiap perwakilan anggota kelompok sesuai tipe soal yang sudah sepakati. Hasil skor turnament siklus 1 RPP 1 (pertemuan 2) disajikan pada Tabel 2 berikut.

Tabel 2. Hasil Skor Turnament Siklus 1, RPP 1

\begin{tabular}{clcccc}
\hline \multirow{2}{*}{ No } & \multirow{2}{*}{ Materi Jenis-jenis BUMN \& BUMD } & \multicolumn{4}{c}{ Jawaban siswa } \\
\cline { 3 - 6 } & & F Benar & $(\%)$ & F Salah & $(\%)$ \\
\hline 1 & Soal A & - & 0 & 6 & 100 \\
2 & Soal B & 0 & 0 & 6 & 100 \\
3 & Soal C & 2 & 33,3 & 4 & 66,6 \\
4 & Soal D & 3 & 50 & 3 & 50 \\
5 & Soal E & 4 & 66,6 & 2 & 33,3 \\
\hline
\end{tabular}

Dari Tabel 2 di atas terlihat bahwa untuk soal tipe A atau sangat sulit belum ada peserta didik yang dapat menjawab, sementara untuk tipe soal E, soal mudah dijawab dengan benar 4 perwakilan kelompok. Selanjutnya Hasil skor turnament 2 siklus 1 (RPP Pertemuan 3) disajikan pada Tabel 3 berikut.

Tabel 3. Hasil Skor Turnament Siklus 1, RPP 2

\begin{tabular}{clcccc}
\hline \multirow{2}{*}{ No } & \multirow{2}{*}{ Kelemahan dan Kelebihan BUMN \& BUMD } & \multicolumn{4}{c}{ Jawaban siswa } \\
\cline { 3 - 6 } & Soal A & 1 & 16,6 & 5 & 83,3 \\
2 & Soal B & 2 & 60 & 4 & 66 \\
3 & Soal C & 2 & 33,3 & 4 & 66 \\
4 & Soal D & 3 & 50 & 3 & 50 \\
5 & Soal E & 6 & 100 & - & 0 \\
\hline
\end{tabular}


Dari Tabel 3 didapat hasil bahwa terdapat sedikit peningkatan kemampuan siswa dalam menjawab soal. Kebenaran siswa untuk menjawab soal-soal dengan tingkat kemampuan mudah sangat baik. Hal ini dapat dilihat dari persentase siswa di kelompok yang menjawab pertanyaan dengan benar. Sementara untuk soal-soal dengan kategori sangat sulit juga sudah menunjukkan peningkatan karena terdapat 3 siswa yang mampu menjawab benar. Kebenaran jawaban menunjukkan peningkatan seiring dengan semakin dikenalnya model-model pertanyaan yang diberikan. Siswa mulai memahami bagaimana bentuk soal yang akan diberikan guru dari kegiatan diskusi dikelompoknya.

\section{Observasi}

Pengamatan terhadap aktivitas dilakukan observer selama penelitian tindakan kelas berlangsung. Selain berdiskusi tentang materi pelajaran di tiap kelompok untuk mempersiapkan diri menjawab soalsoal di turnament, siswa juga diwajibkan mengerjakan lembaran kerja siswa. Setelah proses pembelajaran dengan menggunakan model belajar kooperatif TGT siklus 1 selesai, maka dilaksanakan ulangan harian untuk mengukur ketuntasan hasil belajar siswa pada siklus 1 . Soal ulangan harian terdiri atas 25 soal objektif. Hasil ketuntasan belajar siswa pada siklus 1 disajikan pada Tabel 4 .

Tabel 4. Rekap Hasil Ulangan Harian Siswa Pada Siklus 1

\begin{tabular}{|c|c|c|c|c|}
\hline \multirow[t]{2}{*}{ No } & \multirow[t]{2}{*}{ Kompetensi Dasar } & \multicolumn{2}{|c|}{ Jumlah Siswa } & $\begin{array}{l}\text { Keterangan } \\
(\mathrm{KKM}=80)\end{array}$ \\
\hline & & Tuntas & Tidak tuntas & $\%$ tuntas \\
\hline 1 & Hasil Tes Siklus 1(UH 1 ) & 18 & 12 & 60 \\
\hline
\end{tabular}

\section{Hasil Ketuntasan UH Siklus 1}

Dari data hasil ulangan harian didapatkan hasil ketuntasan belajar pada siklus 1 sebesar 60\%. Hasil ini belum memenuhi target yang diinginkan yakni sebesar 75\% tuntas. Dari data nilai ulangan harian siswa pada siklus 1 , sebagian siswa telah mendapatkan nilai yang baik sedangkan bagi yang belum tuntas dilakukan remedial. Hasil- hasil skor ulangan harian siklus 1 yang didapatkan oleh siswa selanjutnya di konsultasikan pada kategori tingkat pengetahuan sesuai kriteria yang telah ditetapkan. Hasil analisis kategori pengetahuan konsep siswa pada siklus satu disajikan pada Tabel 5.

Tabel 5. Hasil Kategori Pengetahuan Siswa Pada Siklus 1

\begin{tabular}{ccccc}
\hline \multirow{2}{*}{ UH 1 } & \multicolumn{4}{c}{ Kategori } \\
\cline { 2 - 5 } & Amat baik & Baik & Cukup & Kurang baik \\
\hline Jumlah & - & 8 & 15 & 7 \\
\hline
\end{tabular}

\section{Pelaksanaan Pembelajaran Siklus 1}

Bersamaan dengan observasi, siswa membahas pertanyaan di kelompok, kegiatan pembelajaran dilaksanakan sesuai prosedur penelitian tindakan kelas.

\section{Refleksi Siklus 1}

Berdasarkan hasil observasi selama kegiatan yang telah dilakukan pada siklus I, peneliti bersama observer mendiskusikan hasil pengumpulan data dan catatan lapangan yang diperoleh selama pelaksanaan tindakan dan proses pembelajaran, berdasarkan analisis data ditemukan hal-hal sebagai berikut: Pada pertemuan awal siklus 1, melaksanakan indikator Menjelaskan pengertian BUMN dan BUMD, Menjelaskan peran BUMN dan BUMD dalam perekonomian, Menjelaskan bentuk-bentuk BUMN dan BUMD, Menjelaskan jenis-jenis Kegiatan Usaha BUMD, Menjelaskan kebaikan dan kelemahan BUMN dan BUMD, para siswa masih belum terlalu antusias dalam mengkaji dan mengolah lebih jauh materi diskusi. materi yang didiskusikan dalam kelompok juga tidak fokus. Pada pertemuan berikutnya diperbaiki dengan cara guru memberikan poin-point tentang materi diskusi dan indicatorindikator yang harus dikuasai oleh tiap anggota kelompok. Untuk meningkatkan keaktifan diskusi para anggota kelompok, observer beserta guru berkeliling ke masing-masing kelompok dan membantu siswa dalam memecahkan masalah. Pertemuan berikutnya para siswa telah ditugasi untuk membaca materi yang akan dipelajari pada pertemuan berikutnya. Dan pada pertemuan pembelajaran selanjutnya siswa ditugasi dan diharapkan telah membaca materi terlebih dahulu di rumah. Diharapakan dengan telah 
dipelajarinya materi sebelum pembelajaran siswa dapat lebih paham dan proses diskusi dalam kelompok dapat berjalan lebih hidup.

\section{Hasil Siklus 2}

Setelah didapatkan hasil siklus 1 yang ketuntasan hasil belajarnya belum maksimal maka dilanjutkan ke siklus 2. Untuk menguji tingkat ketuntasan dari kompetensi dasar Menjelaskan perbedaan perusahaan swasta dan BUMS, Menjelaskan peran BUMS dalam perekonomian, Menjelaskan bentuk-bentuk BUMS, Menjelaskan kekuatan dan kelemahan BUMS, Menjelaskan jenisjenis kegiatan usaha BUMS, Menjelaskan tahapan mendirikan usaha dalam BUMS..kembali digunakan model belajar yang sama yaitu TGT, tiap siswa tetap diberi pertanyaan dari tingkat mudah ke tingkat sulit dengan beberapa modifikasi.

\section{Tahap Perencanaan dan Tindakan}

Siklus 2 dilaksanakan dalam 3 kali pertemuan yakni pertemuan pertama hari selasa tanggal 13 februari 2018, pertemuan kedua hari selasa tanggal 20 februari 2018, pertemuan ketiga hari selasa tanggal 27 september 2018. Pada tahap ini setelah guru Menjelaskan perbedaan perusahaan swasta dan BUMS, Menjelaskan peran BUMS dalam perekonomian, Menjelaskan bentuk-bentuk BUMS, Menjelaskan kekuatan dan kelemahan BUMS, Menjelaskan jenis-jenis kegiatan usaha BUMS, Menjelaskan tahapan mendirikan usaha dalam BUMS, maka siswa kemudian diarahkan untuk duduk berkelompok kembali dan mengerjakan LKS yang diberikan. Dalam pengerjaan LKS siswa dapat berdiskusi antara sesama anggota di dalam kelompoknya. Setelah pelaksanaan pengerjaan LKS maka salah satu perwakilan anggota kelompok menyampaikan hasil kerja LKS nya. Penyampaian ini hanya diberi waktu 5-10 menit sebagai bukti ketuntasan siswa dalam mengerjakan LKS yang telah diberikan. Pada saat kegiatan mengerjakan LKS, observer mengamati tingkat aktifitas setiap siswa dalam siklus 2 ini.

\section{Tahap Bermain Games}

Setiap anggota di kelompok berdiskusi untuk memilih anggota kelompoknya yang akan menjawab tipe soal yang kategori soal A yang berkategori Sangat sulit, Soal B kategori Sulit, Soal C kategori Sedikit sulit, Soal D kategori Sedang, dan soal Soal E kategori Mudah. Pemilihan didasarkan kesepakatan siswa tanpa ada campur tangan dari guru. Setelah ditentukan tipe soal untuk masingmasing individu siswa maka tiap kelompok berlatih untuk menjawab soal-soal di dalam kelompoknya.Setelah berlatih pada kelompok masing-masing, maka turnament dimulai dengan cara memanggil setiap anggota kelompok sesuai tipe soal. Guru melakukan penilaian terhadap capaian setiap soal yang di jawab siswa dalam kegiatan turnament. Hasil skor turnament siklus 2 disajikan pada Tabel 6.

Tabel 6. Hasil Skor Turnament Siklus 2, RPP 3

\begin{tabular}{cccccc}
\hline \multirow{2}{*}{ No } & \multirow{2}{*}{ Materi Jenis-jenis Kegiatan Usaha BUMS } & \multicolumn{4}{c}{ Jawaban siswa } \\
\cline { 3 - 6 } & Soal A & F Benar & $(\%)$ & F Salah & $(\%)$ \\
\hline 1 & Soal B & 3 & 50 & 3 & 50 \\
2 & Soal C & 4 & 66.6 & 2 & 33.3 \\
3 & Soal D & 4 & 66,6 & 2 & 33.3 \\
4 & Soal E & 4 & 66,6 & 2 & 33.3 \\
5 & & 6 & 100 & - & 0 \\
\hline
\end{tabular}

Dari Tabel 6 di atas terlihat bahwa untuk soal tipe A atau sangat sulit lebih dari $50 \%$ peserta didik sudah dapat menjawab dengan benar, Untuk soal B, C,D persentase ketuntasan menjawab mencapai $60 \%$. sementara untuk tipe soal E, soal mudah dijawab dengan benar oleh setiap perwakilan kelompok. Hasil yang lebih baik ini secara umum menurut peneliti karena siswa sudah terbiasa dengan model permainan TGT. siswa juga telah dapat memprediksi soal-soal yang akan ditanyaakan sebagai hasil dari diskusi di kelompoknya. Selanjutnya Hasil skor turnament 2 siklus 2 (Pertemuan 3) disajikan pada Tabel 7. 
Tabel 7. Hasil Skor Turnament Siklus 2

\begin{tabular}{clccccc}
\hline \multirow{2}{*}{ No } & \multirow{2}{*}{ Materi Tahapan Mendirikan Usaha Dalam BUMS } & \multicolumn{4}{c}{ Jawaban siswa } \\
\cline { 3 - 6 } & & F Benar & $(\%)$ & F Salah & $(\%)$ \\
\hline 1 & Soal A & 5 & 83,3 & 1 & 16,7 \\
2 & Soal B & 5 & 83,3 & 1 & 16,7 \\
3 & Soal C & 5 & 83,3 & 1 & 16,7 \\
4 & Soal D & 6 & 100 & - & 0 \\
5 & Soal E & 6 & 100 & - & 0 \\
\hline
\end{tabular}

Dari Tabel 7 di atas terlihat bahwa Untuk soal tipe B dan C lebih dari 80\% peserta didik sudah dapat menjawab dengan benar, Untuk soal D dan E juga telah dapat dijawab 100\% benar oleh setiap perwakilan peserta didik.

\section{Observasi}

Pada tahap ini, observasi terus dilakukan oleh observer dan guru untuk melihat perkembangan pelaksanaan kegiatan pembelajaran TGT dan aktifitas belajar serta diskusi siswa. Pada siklus 2 ini terdapat Peningkatan kemampuan menjawab cukup signifikan dibandingkan siklus 1 . Beberapa hal yang memungkinkan semakin baiknya hasil yang didapat pada materi ini adalah semakin terbiasanya siswa dalam menjawab pertanyaan sehingga sebelumnya telah melakukan persiapan-persiapan yang matang. Peningkatan nilai juga dapat muncul karena semakin rajinnya siswa bertanya. Setelah proses pembelajaran dengan menggunakan model belajar kooperatif TGT siklus 2 selesai, maka dilaksanakan ulangan harian untuk mengukur ketuntasan hasil belajar siswa pada siklus 2. Soal ulangan harian terdiri atas 25 soal objektif Hasil ketuntasan belajar siswa pada siklus 2 disajikan pada Tabel 8 .

Tabel 8. Rekap Hasil Ulangan Harian Siswa Pada Siklus 2

\begin{tabular}{ccccc}
\hline \multirow{2}{*}{ No } & \multirow{2}{*}{ Kompetensi Dasar yang Diuji } & \multicolumn{2}{c}{ Jumlah Siswa } & \multicolumn{2}{c}{$\begin{array}{c}\text { Keterangan } \\
\text { (KKM= 80) }\end{array}$} \\
\cline { 3 - 5 } & & Tuntas & Tidak tuntas & \% tuntas \\
\hline 1 & Hasil tes siklus 2 (UH 2) & 26 & 4 & 86.5 \\
\hline
\end{tabular}

Dari data hasil ulangan harian didapatkan hasil ketuntasan belajar pada siklus 2 sebesar 86,6\%. Hasil ini telah memenuhi bahkan melebihi target yang diinginkan yakni sebesar $75 \%$ tuntas. Dari data nilai ulangan harian siswa pada siklus 2 sebagian besar siswa telah mendapatkan nilai yang baik sedangkan bagi 4 orang yang belum tuntas dilakukan remedial. Hasil- hasil skor ulangan harian siklus 2 yang didapatkan oleh siswa selanjutnya di konsultasikan pada kategori tingkat pengetahuan sesuai kriteria yang telah ditetapkan. Hasil analisis kategori pengetahuan konsep siswa pada siklus 2 disajikan pada Tabel 9.

Tabel 9. Hasil Kategori Pengetahuan Siswa Pada Siklus 2

\begin{tabular}{cccc}
\hline UH 1 & \multicolumn{4}{c}{ Kategori } \\
Jumlah baik & Baik & Cukup & Kurang baik \\
\hline \multicolumn{4}{c}{ Hasil Ketuntasan Siklus 2}
\end{tabular}

Pengetahuan siswa pada hasil UH siklus 2 mengalami peningkatan dimana yang masuk kategori amat baik sebanyak 5 orang atau sebesar 16,6 \%, kategori baik dan cukup masing-masing sebanyak 20 orang atau sebesar $66,67 \%$ dan 5 orang atau $16,6 \%$.

\section{Pelaksanaan Pembelajaran Siklus 2}

Pelaksanaan pembelajaran dilakukan sesuai Langkah pembelajaran dalam TGT. Yang tertuang di dalam RPP. Setelah guru menjelaskan materi pelajaran maka siswa berkelompok membahas soalsoal yang ditanyakan. Kemudian perwakilan kelompok menyampaikan hasil kerja kelompoknya. Siswa kemudian secara bergantian menjawab pertanyaan yang ada di tournament. 


\section{Refleksi Siklus 2}

Pada pertemuan awal siklus 2 para siswa telah antusias dalam mengkaji dan mengolah lebih jauh materi diskusi. materi yang didiskusikan dalam kelompok juga lebih fokus karena telah terlatih sejak siklus pertama Untuk meningkatkan keaktifan diskusi para anggota kelompok, observer beserta guru terus berkeliling ke masing-masing kelompok dan membantu siswa dalam memecahkan masalah. Pertemuan berikutnya para siswa telah ditugasi untuk membaca materi yang akan dipelajari pada pertemuan berikutnya. Diharapakan dengan telah dipelajarinya materi sebelum pembelajaran siswa dapat lebih paham dan proses diskusi dalam kelompok dapat berjalan lebih hidup. Dari hasil diskusi dengan teman sejawat dan observer, terlihat bahwa dari data yang didapat terjadi peningkatan baik dalam hasil belajar . Pada siklus 2 ini terlihat anak-anak lebih bersemangat dan antusias.

Dilihat dari games menjawab soal yang sulit dapat dikatakan bahwa Kemampuan menjawab benar masih rendah terutama dalam menjawab soal pada tingkat sangat sulit (soal A). Hal ini dapat dikarenakan siswa masih asing dengan cara menjawab soal dan belum focus. Menurut Sanjaya (2008), proses belajar adalah proses yang inspiratif, yang memungkinkan siswa untuk mencoba melakukan sesuatu. Maka ketika siswa telah mengetahui tipe soal, maka berarti siswa sudah memiliki sedikit pengalaman. Jika dilihat dari kategori tingkat pengetahuan siswa yang diambil dari hasil ulangan harian didapatkan bahwa terjadi peningkatan yang sangat signifikan pada kategori amat baik dan baik. Kategori amat baik dan baik pada siklus 2 meningkat cukup tinggi hal ini dapat terjadi menurut peneliti karena kekurangan pada siklus 1 diperbaiki dengan cara guru memberikan poin-point tentang materi diskusi dan indicator apa saja yang mesti diketahui oleh tiap anggota kelompok. Selain itu juga mendorong siswa lebih bersemangat mengisi lembar kerja siswa. Pengetahuan siswa dalam menganalisis soal harus dilatih pada saat pembelajaran sehingga ketika menjumpai soal-soal di berbagai tes siswa telah terbiasa menganalisis. Satriawan (2018) menyatakan keterampilan berpikir tingkat tinggi peserta didik harus selalu dilatih pada proses pembelajaran. Tirto (2017) menyatakan lemahnya daya analisis salah satunya disebabkan masih rendahnya minat membaca siswa Indonesia. Bahkan berdasarkan risetnya setiap 1000 peserta didik di Indonesia hanya 1 orang yang memiliki kegemaran membaca. Ditambahkannya dengan membaca sebuah buku merupakan media yang sangat baik untuk melakukan transfer nilai, menstimulasi kreatifitas, mengembangkan kemampuan berpikir empirik juga dapat menambah daya tangkap, kreatifitas dan logika berpikir serta membentuk karakter yang positif. Sementara menurut data Kemendikbud (2018) rendahnya tingkat analisis peserta didik dapat dipengaruhi oleh 1). Rendahnya kompetensi guru, 2). Tingkat ketidak hadiran guru yang tinggi serta 3). Implementasi kurikulum yang tidak sesuai. Dalam hal ini model TGT memberikan hasil yang cukup baik sehingga dapat dijadikan alternative pembelajaran.

Adanya peningkatan prestasi belajar dengan menggunakan model belajar kooperatif tipe TGT karena siswa telah belajar memahami materi ajar dengan cara berpikir, berdiskusi dan menjawab soal. Pelaksanaan metode ini dikategorikan baik dan dapat dijadikan salah satu pembelajaran yang dapat diterapkan pada prosses pembelajaran selanjutnya. Menurut Saco (2006) model TGT membuat siswa terlibat aktif dan lebih bersemangat karena ada persaingan antar kelompok. Permainan yang dikemas hdalam bentuk tournament ini dapat berperan sebagai alternative atau sebagai review materi pelajaran. Kemampuan guru dalam membangkitkan aktivitas siswa merupakan suatu yang diperlukan selama penelitian berlangsung. Menurut catatan observer, hanya beberapa siswa yang melakukan kegiatan TGT pada awal pertemuan siklus I, siswa yang lainnya hanya bermain-main, menyontek, ketika ditanya oleh guru siswa menjawab tidak memahami dan takut bertanya, malu ditertawakan teman, di saat inilah peranan guru sangat dibutuhkan sebagai fasilitator. Hal ini sesuai dengan pendapat Rogers dalam Dimyati dan Mudjiono (2009), dalam pembelajaran disarankan, agar siswa memperoleh kepercayaan diri untuk mengalami dan menemukan secara bertanggung jawab, hal ini terjadi bila guru bertindak sebagai fasilitator.

Adanya peningkatan hasil belajar dengan menggunakan model belajar TGT diharapkan dapat meningkatkan pengetahuan siswa terhadap permasalahan yang akan ditemui didunia nyata (kontekstual). Pelaksanaan metode ini dikategorikan baik dan dapat dijadikan salah satu pembelajaran 
yang dapat diterapkan pada prosses pembelajaran selanjutnya. Menurut Sanjaya (2008), proses belajar adalah proses yang inspiratif, yang memungkinkan siswa untuk mencoba melakukan sesuatu. Dalam TGT siswa juga dituntut agar dapat belajar mandiri dan berkelompok dengan mencari informasi atau jawaban dari pertanyaan yang timbul sendiri kemudian menyampaikan jawaban/temuannya terhadap pertanyaan tersebut. Jika ini terlaksana maka akan timbul kepercayaan diri dari tiap siswa terhadap kemampuan dirinya sendiri. Hal ini sesuai dengan pendapat Rogers dalam Dimyati dan Mudjiono (2009), dalam pembelajaran disarankan, agar siswa memperoleh kepercayaan diri untuk mengalami dan menemukan secara bertanggung jawab, hal ini terjadi bila guru bertindak sebagai fasilitator.

\section{SIMPULAN DAN SARAN Simpulan}

Berdasarkan hasil penelitian yang penulis laksanakan di MAN-1 Pekanbaru di kelas XI IIS 2, diperoleh kesimpulan bahwa hasil belajar siswa dalam mata pelajaran Ekonomi dengan menggunakan model pembelajaran kooperatif tipe Team Games Tournament (TGT) menunjukkan peningkatan dari siklus 1 ke siklus 2 .

\section{Saran}

Model belajar kooperatif tipe TGT dapat dijadikan alternatif model pembelajaran untuk perbaikan hasil belajar bagi pelajaran pelajaran lain. Model belajar kooperatif tipe TGT dapat dikolaborasikan dengan metode lain agar lebih dapat memaksimalkan kreatifitas dan aktifitas anak. 


\section{DAFTAR RUJUKAN}

Asbullah. (2008). Peningkatan Soft Skill Guru yang Cerdas dan Inovatif. Pekanbaru: Simposium Biologi FKIP.

Suharsimi Arikunto, Suhardjono, Supardi. (2003). Penelitian Tindakan Kelas. Jakarta: Bumi Aksara.

BNSP. (2006). Petunjuk Teknis Pengembangan Silabus dan Contoh/Model Silabus SMA/MA. Jakarta: Departemen Pendidikan Nasional.

Dimyati dan Mujiono. (2002). Belajar dan Pembelajaran. Jakarta: Rineka Cipta.

Depdiknas. (2004). Rambu-rambu Penetapan Standar Ketuntasan Belajar Minimum dan Analisis Hasil Pencapaian Standar Ketuntasan Belajar. Jakarta.

Dimyati dan Mujiono. (2009). Belajar dan Pembelajaran. Jakarta: Rineka Cipta.

Hamalik Oemar. (2014). Kurikulum dan Pembelajaran. Jakarta: Penerbit Bumi Aksara.

Rusman. (2011). Model-Model Pembelajaran. Jakarta: Raja Grafindo Persada.

Wina Sanjaya. (2008). Perencanaan dan desain sistem pembelajaran. Jakarta: Kencana.

Sumiati, Asra. (2007). Metode Pembelajaran. Bandung: CV. Wacana Prima.

Robert E. Slavin. (2010). COOPERATIVE LEARNING: Teori, Riset dan Praktik. Bandung: Nusa Media.

Satriawan. (2018). http: www. Republika.co. id. [Diakses 10 maret 2018].

Silberman Mell. (1996). Active Learning. Yogyakarta: Yappendis.

Surya. (1992). Psikologi Pendidikan. Bandung: IKIP Bandung.

Sukwiaty. (2009). Pengertian Ilmu Ekonomi. Jakarta: Rineka Cipta.

Tirto. (2017). Potret Anak Indonesia, Lemah nalar Karena Kurang Membaca. http: // tirto. id/potret-anakindonesia. [Diakses 10 Maret 2018].

Trianto. (2010). Mendesain Model Pembelajaran Inovatif-Progresif: Konsep landasan dan Implementasinya Pada Kurikulum Tingkat satuan Pendidikan. Jakarta: Kencana. 